\title{
Geochemistry of Rare Earth Elements in Pacific Hydrothermal Sediments
}

\author{
ROBERT M. OWEN and ANNETTE M. OLIVAREZ \\ Department of Geological Sciences, University of Michigan, Ann Arbor, MI 48109 (U.S.A.)
}

(Received August 25, 1987; revision accepted March 20, 1988)

\begin{abstract}
Owen, R.M. and Olivarez, A.M., 1988. Geochemistry of rare earth elements in Pacific hydrothermal sediments. Mar. Chem., 25: 183-196.

The concentrations and mass accumulation rates of rare earth elements (REE) in hydrothermal sediments from two Pacific sites support earlier predictions that hydrothermal REE input: are significant to the overall marine REE mass balance. Although REE are enriched in hydrothermal vent fluids, they are rapidly and extensively scavenged from the water column by $\mathrm{F}_{\mathrm{B}}$ oxyhydroxides and undergo some degree of fractionation prior to removal. Evidence for significant light REE (LREE) hydrothermal inputs tends to be masked by the fact that the LREE patterns and inter-element ratios of both proximal and distal hydrothermal precipitates are similar to those of seawater. However, the heavy REE (HREE) patterns clearly reflect a basaltic source and the HREE ratios from both sites are similar to each other but distinct from their seawater analogs. This suggests HREE ratios potentialy could be used as proxy indicators in our attempts to reconstruct the history of seafloor hydrothermal activity.
\end{abstract}

\section{INTRODUCTION}

The most recent comprehensive review of the aqueous and sedimentary geochemistry of the rare earth elements (REE) is contained in the excellent summary compiled by Fleet (1984). Both this review and more recent studies show that a dominant research theme in this subject has involved attempts to understand the processes which supply or remove REE to and from the marine environment, and the question of whether these elements are in mass balance in the oceans. For example, Piper (1974) attempted to compute a mass balance for the REE by comparing REE input rates with REE mass accumulation rates in various Pacific pelagic sedimentary phases. These calculations indicated that REE removal rates were 11-18 times greater than their river input rates, or (by including extrapolated estimates of basalt inputs) 11-14 times greater than river-plus-basalt inputs. Piper (1974) suggested three possible explanations which might account for the apparent imbalance. First, he noted that his 
estimates of REE river inputs may have been too low (at that time dissolved REE concentration data were available only for the Gironde River system in France, and he was forced to assume that these data represented world average concentrations ). Second, he suggested REE may be enriched in surficial sediments due to remobilization during early diagenesis - a process which would be manifested as artificially high REE mass accumulation rates (MARs) in the surficial sediments. Finally, he noted that significantly greater amounts of REE might be entering the system from submarine volcanic activity than were represented in his budget calculations.

Subsequent investigations have dealt primarily with various aspects of each of the first two of these possibilities. Additional data pertaining to REE concentrations in rivers (Kolesov et al., 1975; Varshal et al., 1975; Martin et al., 1976; Keasler and Loveland, 1982) indicate that the Gironde River values may indeed be somewhat lower than world average concentrations, but the significance of this to the REE mass balance remains unclear because of uncertainties about the extent to which REE river inputs are controlled by particle transport (Hoyle et al., 1984). Similarly, evidence now exists that REE can undergo diagenetic remobilization in lacustrine (Owen and Mackin, 1980) and highly reducing nearshore sediments (Elderfield and Sholkovitz, 1987), but not in the relatively more oxidizing sediments of the open ocean basins.

The present study is concerned with the third of the aforementioned possible explanations regarding the REE imbalance: significant REE inputs from seafloor hydrothermal activity. Widespread seafloor hydrothermal activity had not yet been discovered at the time of Piper's (1974) study. Moreover, it was recognized that the REE patterns of metalliferous sediments were quite similar to those of seawater (Bender et al., 1971; Dymond et al., 1973; Piper and Graef, 1974 ), which indicated that seawater was the source of REE for these sediments and supported the interpretation that hydrothermal inputs contributed insignificantly to the REE budget of marine sediments. However, Piper (1974) observed that quite the opposite would be true if hydrothermal sediments accumulated REE at a much faster rate than other pelagic sediments. Based on a detailed chemical analysis of an iron-rich hydrothermal deposit from the Dellwood Seamount, Piper et al. (1975) also noted that basaltic REE contributions may be unambiguously preserved only in the immediate vicinity of hydrothermal inputs, and that more extensive volcanogenic contributions could be masked by contributions from other sources such as seawater. Following the initial discovery of active hydrothermal venting in 1977 (Corliss et al., 1979), seafloor hydrothermal activity has become recognized as a widespread and pervasive marine process of profound significance to the global heat budget, marine geochemical cycles, the formation of metalliferous mineral deposits, and chemosynthetic processes in the marine biosphere (Rona et al., 1983). High temperature venting has now been documented in association with the full spectrum of submarine volcanic activity: slow to fast spreading ridges, sea- 
mounts, and back arc basins; and in sediment-hosted and sediment-starved settings (McDuff, 1987). The chemical exchanges which occur via seawaterbasalt interactions during hydrothermal circulation are of sufficient magnitude to influence the mass balance of several of the major chemical species in seawater (Edmond et al., 1979), and both direct and indirect measurements (e.g. Dymond, 1981; Lupton and Craig, 1981) have shown that emanations from hydrothermal vents are transported thousands of $\mathrm{km}$ from the ridge axis. Of direct relevance to the REE budget question, Michard and Albarede (1986) have recently reported highly enriched REE concentrations in hydrothermal vent fluids. These discoveries suggest REE inputs from hydrothermal sources may play a more important role in the REE budget than was previously suspected. Here we attempt to investigate this role by examining the REE geochemistry of Pacific hydrothermal sediments.

\section{METHODS AND SAMPLE DESCRIPTION}

The chemical data discussed in this report were obtained from the analysis of sediment cores collected from two areas of known seafloor hydrothermal activity in the Pacific. The first of these was recovered $\sim 1150 \mathrm{~km}$ west of the axis of the East Pacific Rise (EPR) at $19^{\circ} \mathrm{S}$, at Deep Sea Drilling Project (DSDP) Site $598\left(19^{\circ} 0.283^{\prime} \mathrm{S}, 124^{\circ} 40.606^{\prime} \mathrm{W}\right)$. The $43 \mathrm{~m}$ column of sediments from this site represents a complete record of hydrothermal sedimentation along the western flank of the EPR during the past 16 million years. A detailed description of the procedures used to analyze the 50 samples taken from this core, as well as the geochemical and mass accumulation rate data, are given by Ruhlin and Owen $(1986 \mathrm{a}, \mathrm{b})$. The second core was obtained during a 1985 cruise of the R/V "Surveyor" as part of the National Oceanic and Atmospheric Administration's VENTS Program. This was an $80 \mathrm{~cm}$ Kasten core. designated $\mathrm{KC}-1$, recovered from a water depth of $2635 \mathrm{~m} \sim 15.6 \mathrm{~km}$ west $\left(44^{\circ} 44.21^{\prime} \mathrm{N}, 130^{\circ} 33.38^{\prime} \mathrm{W}\right)$ of the axis of the Southern Juan de Fuca Ridge (SJFR). The whole spreading rate in this area is $6 \mathrm{~cm} \mathrm{year}^{-1}$ (Vine, 1966) and age dating of $\mathrm{KC}-1$ sediments yields a linear sedimentation rate of $6.1 \times 10^{-4}$ $\mathrm{cm} \mathrm{year}^{-1}$ (G. Massoth, personal communication, 1986). Assuming a constant linear sedimentation rate, we estimate the sediments in $\mathrm{KC}-1$ include the upper $24 \%$ of the total sediment cover to basement and represent hydrothermal deposition during the past 130000 years. A total of 20 samples collected at intervals of $1-5 \mathrm{~cm}$ were taken from this core, freeze-dried, and ground with mortar and pestle prior to analysis. Each sample was analyzed for the elements $\mathrm{Al}, \mathrm{Ba}, \mathrm{Co}, \mathrm{Fe}, \mathrm{Mg}, \mathrm{Mn}, \mathrm{Ni}, \mathrm{Si}$ and $\mathrm{Ti}$, and the rare earth elements $\mathrm{La}, \mathrm{Ce}, \mathrm{Nd}$, $\mathrm{Sm}, \mathrm{Eu}, \mathrm{Tb}, \mathrm{Yb}$ and $\mathrm{Lu}$ by instrumental neutron activation analysis (INAA) at the Phoenix Memorial Laboratory, University of Michigan, using standard INAA procedures (Gordon et al., 1968; Dams and Robbins, 1970). Sediment MARs were calculated using the porosity data from the freeze-drying process 
and assuming an average grain density of $2.65 \mathrm{~g} \mathrm{~cm}^{-3}$. Calcium carbonate was measured using a conventional pressure bomb technique, and biogenic silica was determined using the alkaline extraction procedure of DeMaster (1981). Statistical analyses of the chemical data were performed using the Q-Mode factor analysis procedure of Leinen and Pisias (1984), kindly provided to us by these authors, and using MIDAS, a package of computer programs provided by the Statistical Research Laboratory at the University of Michigan (Fox and Guire, 1976).

\section{RESULTS AND DISCUSSION}

A comparison of recent studies reporting REE abundances in hydrothermal vent fluids versus those in seawater near hydrothermal vents provides considerable insight into both the relative amounts and ultimate fate of REE hydrothermal inputs. The most direct evidence for significant hydrothermal inputs of REE comes from the analysis of samples of hydrothermal vent waters. $\mathrm{Mi}$ chard and Albarede (1986) have reported REE analyses for vent fluids sampled using manned submersibles at $13^{\circ} \mathrm{N}$ and $21^{\circ} \mathrm{N}$ (Table 1). The temperature, $\mathrm{pH}$, and $\mathrm{Mg}$ concentration data from both the $13^{\circ} \mathrm{N}$ site (determined by Von Damm et al., 1985) and the $21^{\circ} \mathrm{N}$ site (determined by Grimaud et al., 1984) indicate that the vent samples represent nearly pure hydrothermal fluids. Each of these vent sites was sampled at a depth of $\sim 2600 \mathrm{~m}$. Depth profiles of REE in the Pacific show that dissolved REE concentrations increase with depth by a factor of 2-3 in the upper $3 \mathrm{~km}$ of the water column (de Baar et al., 1985).

TABLE 1

Actual and normalized REE concentrations in EPR vent fluids ${ }^{*}$

\begin{tabular}{|c|c|c|c|}
\hline & \multicolumn{2}{|c|}{ Vent site ${ }^{b}$} & \multirow{2}{*}{$\begin{array}{l}\text { Normalized } \\
\text { concentration }\end{array}$} \\
\hline & $13 \mathrm{~N}$ & $21^{\circ} \mathrm{N}$ & \\
\hline Temperature $\left({ }^{\circ} \mathrm{C}\right)$ & 320 & 350 & \\
\hline $\mathrm{pH}$ & $<3.9$ & 3.5 & \\
\hline $\mathrm{Mg}(\mathrm{mM})$ & 5.05 & 1.96 & \\
\hline $\mathrm{Ce}\left(\mathrm{ng} \mathrm{kg}^{-1}\right)$ & 1940 & 1514 & 4200 \\
\hline $\mathrm{Nd}\left(\mathrm{ng} \mathrm{kg}^{-1}\right)$ & 1134 & 380 & 130 \\
\hline Sm (ng kg $\left.{ }^{-1}\right)$ & 486 & 104 & 210 \\
\hline $\mathrm{Eu}\left(\mathrm{ng} \mathrm{kg}{ }^{-1}\right)$ & 805 & 232 & 1470 \\
\hline $\mathrm{Gd}\left(\mathrm{ng} \mathrm{kg}^{-1}\right)$ & 265 & 85 & 86 \\
\hline $\mathrm{Yb}\left(\mathrm{ng} \mathrm{kg}{ }^{-1}\right)$ & 48 & 33 & 14 \\
\hline
\end{tabular}

${ }^{a} \mathrm{REE}$ data in $\mathrm{ng} \mathrm{kg}{ }^{-1}$ from Miehard and Albarede (1986); other data from Von Damm et al. (1985) and Grimaud et al. (1984).

${ }^{\mathrm{b}}$ Average of samples $14 \mathrm{Ti} 2$ and $20 \mathrm{Ti} 4$ from $13^{\circ} \mathrm{N}$, and samples $1160-2$ and $1158-2$ from $21^{\circ} \mathrm{N}$.

'Average value for both sites divided by Pacific seawater concentration at $2750 \mathrm{~m}$ from de Baar et al. (1985). 
Consequently, in order to make meaningful comparisons, the values shown in Table 1 include both the measured REE concentrations in the vent fluids and depth-normalized concentrations. The normalized concentrations were obtained by dividing the average REE concentration in the vent waters from both sites by analogous REE concentrations in Pacific seawater from a depth of $2750 \mathrm{~m}$ (de Baar et al., 1985). These normalized values show that REE concentrations in hydrothermal vent fluids are enriched between 14 and 4200 times relative to their concentrations in seawater at a similar depth.

Klinkhammer et al. (1983) have determined REE concentrations in seawater samples collected from a depth of $2500 \mathrm{~m}$ in the immediate vicinity of two known hydrothermal vent fields: in the northwest Pacific (Mariana Trough; $\left.18^{\circ} \mathrm{N}, 145^{\circ} \mathrm{E}\right)$, and in the southeast Pacific $\left(19^{\circ} \mathrm{S}\right.$ at the crest of the EPR). These data are summarized in Table 2, where again we have calculated depthnormalized REE concentrations. A remarkable contrast exists between the normalized REE concentrations in Tables 1 and 2. Despite significant REE enrichments in hydrothermal vent fluids, dissolved REE concentrations in seawater near vent fields are actually depleted relative to normal seawater at a similar depth. This comparison suggests that hydrothermal REE inputs are both rapidly and extensively removed from the water column in close proximity to their source.

Klinkhammer et al. (1983) suggested the mechanism responsible for REE removal from vent fluids may involve scavenging by $\mathrm{Fe}$ and $\mathrm{Mn}$ oxidation products discharged in the hydrothermal effluents. Ruhlin and Owen (1986a,b) have observed that the sediments at DSDP Site 598 represent an excellent sample suite for examining the proposed scavenging mechanism over a geologically significant time period. These sediments represent a complete 16 million

\section{TABLE 2}

Actual and normalized REE concentrations $\left(\mathrm{ng} \mathrm{kg}^{-1}\right)$ from seawater near hydrothermal vents ${ }^{\mathrm{a}}$

\begin{tabular}{llll}
\hline & $\begin{array}{l}\text { NW Pacific } \\
(2500 \mathrm{~m})\end{array}$ & $\begin{array}{l}\text { SE Pacific } \\
(2500 \mathrm{~m})\end{array}$ & $\begin{array}{l}\text { Normalized } \\
\text { concentration }\end{array}$ \\
\hline $\mathrm{La}$ & 6.5 & 4.2 & 0.61 \\
$\mathrm{Ce}$ & 1.3 & 0.49 & 2.2 \\
$\mathrm{Nd}$ & 4.3 & 2.3 & 0.53 \\
$\mathrm{Sm}$ & 0.80 & 0.41 & 0.43 \\
$\mathrm{Eu}$ & 0.21 & 0.12 & 0.47 \\
$\mathrm{Gd}$ & 1.3 & 0.79 & 0.52 \\
$\mathrm{Yb}$ & 1.4 & 1.3 & 0.46 \\
\hline
\end{tabular}

${ }^{\mathrm{a}}$ From Klinkhammer et al. (1983). The NW Pacific site is the Mariana Trough; the SE Pacific site is EPR at $19^{\circ} \mathrm{S}$.

${ }^{\mathrm{b}}$ Average value for both sites divided by Pacific seawater concentration at $2750 \mathrm{~m}$ from de Baar et al. (1985). 
year period of hydrothermal materials deposited at distances ranging from 9 to $1139 \mathrm{~km}$ from the paleo-rise crest. Moreover, the Site 598 sediments are lithologically simple, primarily consisting of a mixture of hydrothermal materials and biogenous carbonates; the composition of the hydrothermal component is essentially constant through space and time; and the sediments have undergone minimal diagenetic alteration. Ruhlin and Owen's (1986a,b) results strongly support the scavenging hypothesis. The REE concentrations of Site 598 sediments increase between 1 and 2 orders of magnitude, and the shale-normalized REE pattern becomes more seawater-like (e.g. the Ce anomaly) as the sediments are deposited at increasing distances from the rise crest (Fig. 1).

Here we attempt to provide further clarification regarding the responsible agent and the timing of the scavenging process. The suggestion (Klinkhammer et al., 1983) that $\mathrm{Fe}$ and/or $\mathrm{Mn}$ oxidation products are responsible for scavenging REE is quite reasonable. Hydrous oxides of $\mathrm{Fe}$ and $\mathrm{Mn}$, either as discrete particles or as coatings on clay minerals, are known to incorporate large quantities of various trace elements by adsorption or coprecipitation reactions (Chester and Aston, 1976). (In fact, prior to the advent of modern analytical instrumentation, analytical chemists commonly would concentrate and remove REE from dilute solutions by coprecipitation with $\mathrm{Fe}$ oxyhydroxides.) Direct scavenging by either Fe or Mn hydrous oxides should be manifested by two trends in the data. First, there should be a direct relationship between the mass accumulation rates (MARs) of the REE and the scavenging element. As shown in Fig. 2, a highly significant correlation $(p<0.01)$ exists between the MARs of $\mathrm{Fe}$ and the REE (except $\mathrm{Ce}$ ); correlations between the MARs of Mn

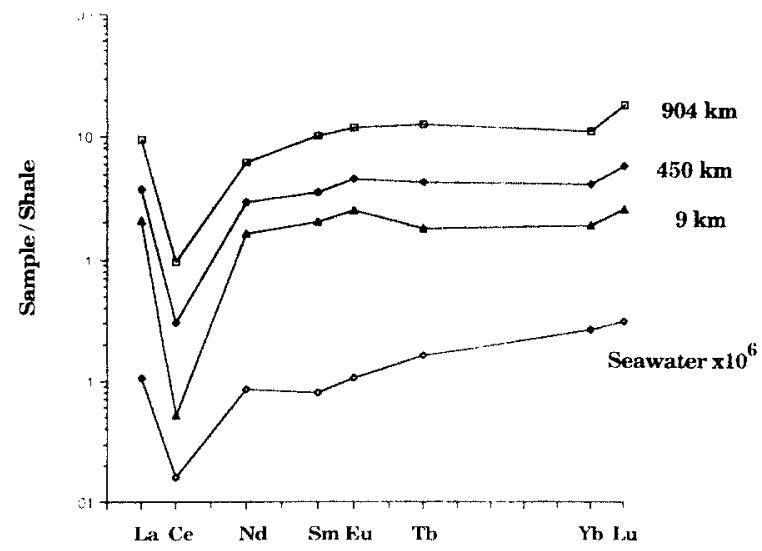

Fig. 1. Shale-normalized REE patterns for Site 598 samples (from Ruhlin and Owen, 1986a) and seawater (from Hogdahl et al., 1968). Note that absolute REE abundances increase and that REE patterns become more seawater-like with increasing distance from the paleo-rise crest. 


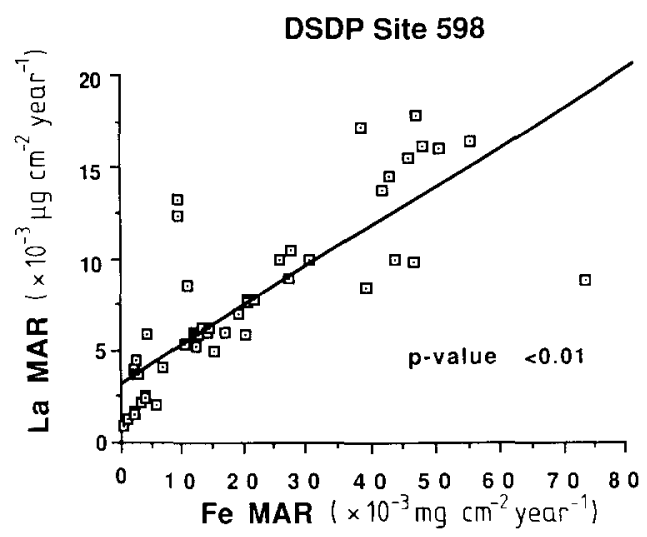

Fig. 2. Correlation between MARs of La and Fe in Site 598 hydrothermal sediments. Other REE (except $\mathrm{Ce}$ ) exhibit a similar relationship.

and the REE are either not significant or less significant than that observed for $\mathrm{Fe}$.

The second expected trend is based on the accumulation pattern of hydrothermal precipitates. Lyle et al. (1986, 1987) have modeled this process using data from DSDP Sites 597-600C, and found that the accumulation of hydrothermal precipitates decreases exponentially with increasing distance away from the rise crest. This type of pattern is due to the combined effects of the injection of hydrothermal precipitates into seawater at vents, the slow horizontal transport of these materials, and precipitate settling. However, while the concentration of scavenging agents decreases markedly away from the rise crest, the distal precipitates have had more exposure to seawater (i.e. a relatively greater opportunity to scavenge REE from the water column). Consequently, we would expect to observe an inverse relationship between the concentrations of the REE and the scavenging agent. This relationship is observed $(p<0.01)$ for the REE and Fe concentrations (Fig. 3); inverse correlations between the REE and Mn concentrations are either not significant or less significant than that observed for Fe. We conclude from these trends that Fe rather than Mn oxyhydroxides are the primary scavenging agents for the REE. This is consistent with the findings of Elderfield et al. (1981a,b), who noted that the REE contents of a suite of pacific ferromanganese nodules primarily reflect the proportions of the iron-rich phase of the nodules.

The 20 samples from core KC-1 (SJFR) are younger (130 000 years to the present) than the uppermost sample from Site 598 (170 000 years), and thus they allow a roughly 20 -fold improvement in our ability to examine the REE geochemistry of Recent hydrothermal sediments. The geochemical data from $\mathrm{KC}-1$ were analyzed statistically using the modified Q-Mode factor analysis technique of Leinen and Pisias (1984), which is designed to determine the 


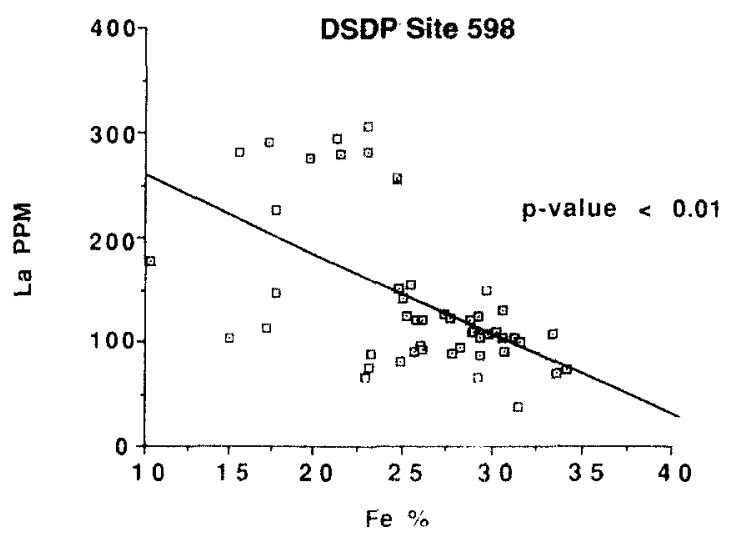

Fig. 3. Correlation between the concentrations of La and Fe in Site 598 hydrothermal sediments. Other REE exhibit a similar relationship.

number and actual chemical composition of significant geochemical end-members which are present in geological mixtures, such as marine sediments. The details of this statistical analysis are the subject of a separate report (Olivarez and Owen, 1987); consequently; only those results relevant to the present study are summarized here.) The $\mathbf{Q}$-Mode factor analysis procedure identified three factors or end-members in the SJFR sediments, which collectively account for $97 \%$ of the total variance in the geochemical data. Each of these factors was interpreted by comparing key inter-element ratios determined from the predicted composition of each factor with similar ratios for geochemically 'pure' end-members reportẹd in the literature (Dymond, 1981; Graybeal and Heath, 1984). Based on this comparison, we consider these three factors to represent a proximal hydrothermal, a distal hydrothermal, and a detrital end-member. The proximal hydrothermal end-member has a $\mathrm{Mn} / \mathrm{Fe}$ ratio of 0.07 , which is in good agreement with values of $0.06-0.07$ for basal hydrothermal sediments (Bonatti and Joensuu, 1966; Piper et al., 1975), while the distal hydrothermal end-member has a $\mathrm{Mn} / \mathrm{Fe}$ ratio of 0.43 , which is close to the range $0.3-0.4$ reported for typical hydrothermal sediments (Graybeal and Heath, 1984).

The REE patterns of the light REE (LREE) of both hydrothermal endmembers áre quite similar to that of seawater, while the heavy REE (HREE) patterns,' especially of the proximal end-member, are more similar to that of basalt (Fig. 4). This suggests the LREE undergo fairly extensive mixing with seawater before they are scavenged from the fluid phase. The HREE are generally considered to form more stable and soluble complexes than the LREE in seawater, which renders them less susceptible to removal from the aqueous phase and accounts for their relative enrichment in the typical seawater REE pattern (e.g. Fleet, 1984). The absence of such a pronounced HREE enrichment in the hydrothermal end-members, and the similarity between the HREE 


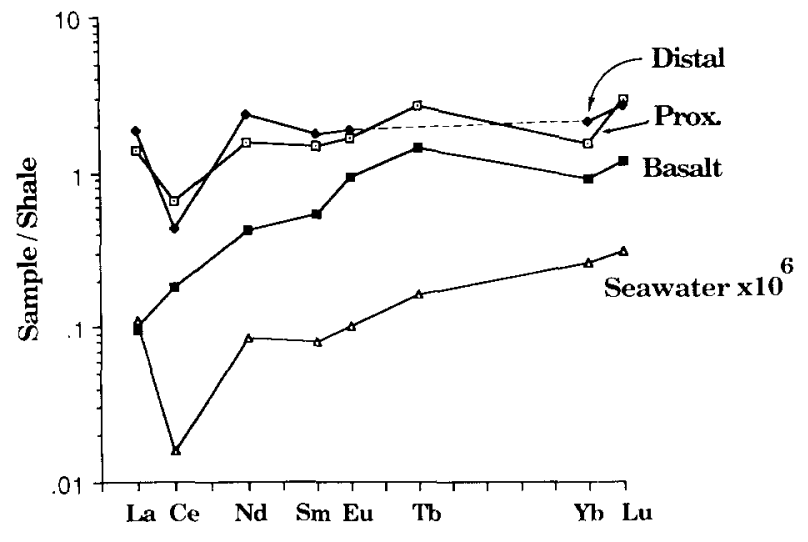

Fig. 4. Comparison of REE patterns for proximal and distal hydrothermal sediments from SJFR with seawater (from Høgdahl et al., 1968) and basalt (from Erzinger, 1986). Note similarities between LREE patterns and seawater and between HREE patterns and basalt.

TABLE 3

Comparison of REE ratios for hydrothermal sediments, seawater and basalt

\begin{tabular}{|c|c|c|c|c|}
\hline \multirow[t]{2}{*}{ Description $^{\mathrm{a}}$} & \multicolumn{2}{|l|}{ LREE } & \multicolumn{2}{|l|}{ HREE } \\
\hline & $\mathrm{La} / \mathrm{Sm}$ & $\mathrm{La} / \mathrm{Eu}$ & $\mathrm{Eu} / \mathrm{Yb}$ & $\mathrm{Eu} / \mathrm{Lu}$ \\
\hline Proximal hydrothermal (KC-1) & 5.23 & 20.9 & 0.44 & 1.49 \\
\hline Distal hydrothermal (KC-1) & 5.94 & 25.7 & 0.36 & 1.80 \\
\hline Site 598 (9 $\mathrm{km}$ from ridge axis) & 5.76 & 21.9 & 0.52 & 2.45 \\
\hline Site 598 (average) & 5.87 & 20.5 & 0.37 & 1.78 \\
\hline Seawater & 7.56 & 26.1 & 0.16 & 0.87 \\
\hline Basalt & 1.12 & 2.94 & 0.35 & 2.18 \\
\hline
\end{tabular}

${ }^{a}$ Ratios for seawater from Høgdahl et al. (1968); for basalt from Erzinger (1986).

patterns of these end-members and basalt (Fig. 4), suggests that the HREE introduced from vent fluids are either scavenged before complete mixing has occurred, or else are scavenged after mixing but before the HREE can form stable aqueous complexes. The LREE patterns (Fig. 4) clearly support the contention of Piper et al. (1975) that extensive REE inputs from hydrothermal sources could be masked by contributions from other sources, particularly seawater. On the other hand, the HREE patterns suggest that certain interelement ratios among the HREE could be useful in identifying hydrothermal contributions to the REE sediment budget. For example, in Table 3 we show a comparison between LREE and HREE ratios for the proximal and distal hydrothermal materials from the SJFR, hydrothermal sediments from Site 598, seawater and basalt. In all cases the LREE ratios of the hydrothermal mate- 
rials are obviously closer to the seawater values, but the HREE ratios are more indicative of a basaltic source. There is also reasonably good agreement between the values of these ratios for the hydrothermal sediments from $19^{\circ} \mathrm{S}$ and the SJFR. This is a promising finding which warrants further study. Marine geochemists have long sought to identify characteristic elemental ratios which can serve as indicators for specific sedimentary components. For example, characteristic ratios among such elements as $\mathrm{Fe}, \mathrm{Mn}, \mathrm{Co}, \mathrm{Ni}$ and $\mathrm{Zn}$ have been useful in determining the relative amounts of lithogenous, biogenous, authigenic, and hydrothermal components in mixtures of sedimentary materials (Dymond, 1981; Graybeal and Heath, 1984). This information, in turn, can be used to determine the areal distribution or depositional history of these same components. Unfortunately, many of the characteristic ratios involve elements which are highly susceptible to diagenetic remobilization, in which case the assumption of ratio constancy is no longer valid. However, the REE are generally considered to be unaffected by diagenesis (Fleet, 1984), except in strongly reducing sediments (Elderfield and Sholkovitz, 1987) which are atypical of the open ocean basin. Thus highly stable ratios among the HREE in hydrothermal materials could be useful in determining the spatial and tem. poral distribution of these materials in marine sediments.

In his mass balance calculations, Piper (1974) assumed that REE removal was primarily reflected in the REE concentrations of the non-lithogenous (i.e. biogenic and authigenic) components of Pacific pelagic sediments. Consequently, his estimate that REE removal rates exceed REE river input rates by a factor of 11-18 was based on a comparison of the MARs of REE in the non. lithogenous sediment component versus REE river inputs. By comparing the $\mathrm{REE} / \mathrm{Fe}$ ratios of vent fluids versus hydrothermal sediments, Olivarez and Owen (1987) have shown that hydrothermal REE inputs are rapidly and extensively scavenged from the water column by $\mathrm{Fe}$ oxyhydroxides. Consequently, significant REE inputs from hydrothermal sources in the nonlithogenous sediment component would tend to minimize this apparent imbalance, because they would represent an unrecorded input in the mass balance calculations. A comparison of the MARs of REE in the non-lithogenous component of Pacific pelagic sediments with the MARs for the hydrothermal sediments from the two sites discussed in this study is shown in Table 4. Except for $\mathrm{Ce}$, these data indicate the MARs of REE in hydrothermal sediments are 2-6 times greater than those of all non-lithogenous sources combined. We emphasize that this comparison is useful in a qualitative sense only. A detailed quantitative assessment (i.e. a recalculation of the REE mass balance) would require data not presently available, including more information concerning river inputs and possible diagenetic inputs, as well as data pertaining to the absolute amounts and areal distribution of hydrothermal sediments. Nevertheless, it is clear from the above discussion that inputs from seafloor hydrothermal activity play a significant role in the marine geochemical cycle of the REE. 
TABLE 4

Comparison of REE mass accumulation rates $\left(\times 10^{-12} \mathrm{~kg} \mathrm{~cm}^{-2}\right.$ year $\left.{ }^{-1}\right)$ in different sediment types

\begin{tabular}{llll}
\hline Element & $\begin{array}{l}\text { Non-lithogenous } \\
\text { pelagic Pacific }\end{array}$ & \multicolumn{2}{l}{ Hydrothermal } \\
\cline { 3 - 4 } & & SJFR $^{\mathrm{b}}$ & EPR, 19 S \\
\hline $\mathrm{La}$ & 2.91 & 5.5 & 13.4 \\
$\mathrm{Ce}$ & 4.55 & 4.8 & 2.30 \\
$\mathrm{Nd}$ & 2.90 & - & 11.9 \\
$\mathrm{Sm}$ & 0.59 & 0.94 & 2.26 \\
$\mathrm{Eu}$ & 0.15 & 0.23 & 0.60 \\
$\mathrm{~Tb}$ & 0.12 & 0.19 & 0.31 \\
$\mathrm{Yb}$ & 0.38 & 0.56 & 1.15 \\
$\mathrm{Lu}$ & 0.07 & 0.15 & 0.25 \\
\hline
\end{tabular}

${ }^{\mathrm{a}}$ From Piper (1974).

"Average of proximal and distal components from core $\mathrm{KC}-1$.

"Average of samples deposited 9-28 km from paleo-rise crest from Ruhlin and Owen (1986a, b).

\section{CONCLUSIONS}

The concentrations of REE in hydrothermal vent fluids are significantly enriched relative to their concentrations in seawater. Similar enrichments are not observed in seawater near vents, however, because the REE are rapidly scavenged from the water column. Highly significant correlations between the concentrations and MARs of the REE and $\mathrm{Fe}$ in hydrothermal precipitates indicate that $\mathrm{Fe}$ oxyhydroxides act as the primary scavenging agents.

The REE patterns and REE ratios of proximal and distal hydrothermal precipitates reveal some degree of fractionation between the REE introduced from vents: $L R E E$ patterns and ratios are quite similar to those of seawater, whereas HREE patterns and ratios reflect a basaltic source. This fractionation implies there are fundamental differences in the geochemical behavior of the REE during the processes involving the mixing of vent fluids and seawater, the formation of Fe oxyhydroxide precipitates, and the scavenging of REE by these precipitates. The observed patterns and ratios suggest the LREE are extensively mixed with seawater prior to scavenging, while the HREE are either scavenged before mixing is complete, or else are scavenged after mixing but before the HREE form stable aqueous complexes in seawater.

The REE ratios and the MARs from both sites discussed here strongly support the predictions of Piper (1974) and Piper et al. (1975) that hydrothermal REE inputs may play an important role in the marine REE budget, but evidence for such contributions tends to be masked by REE contributions from other sources, such as seawater. However, the observed similarities between the HREE ratios of both North and South Pacific hydrothermal sediments, 
which differ significantly from their seawater analogs, may ultimately serve as a tool to identify hydrothermal contributions to sediments. If future studies can demonstrate that hydrothermal sediments in general have characteristic HREE ratios, these could be used as both paleo- and proxy indicators in our attempts to reconstruct the history of seafloor hydrothermal activity in the world ocean.

\section{ACKNOWLEDGMENTS}

The samples used in this study were obtained during a 1983 cruise of the "Glomar Challenger", sponsored by the Deep Sea Drilling Project of the National Science Foundation, and during a 1985 cruise of the "Surveyor", sponsored by the VENTS program of the National Oceanic and Atmospheric Administration. We wish to thank the crew members of these vessels and our colleagues who were members of the scientific parties on these cruises for their assistance in obtaining these samples. E. Birdsall, P. Knoop, and D. Ruhlin rendered valuable assistance in the sample treatment and INAA procedures. The authors have benefited from informal discussions about the marine geochemistry of REE with G. Klinkhammer, M. Lyle, M. Palmer and K. Von Damm. We are grateful to $M$. Lyle and D. Piper for comments and suggestions they offered based on a formal review of an earlier version of this paper. This research was supported in part by the National Science Foundation under Grant No. OCE-8410034, a Rackham Faculty Research Award, a Scott Turner Earth Science Award, and the Michigan Sea Grant College Program, project number RER-17 under grants NA85A-D-SG045 and NA86AA-D-SG043 from the office of Sea Grant, National Oceanic and Atmospheric Administration, U.S. Dept. Commerce, and funds from the State of Michigan. The U.S. government is authorized to produce and distribute reprints for governmental purposes notwithstanding any copyright notation hereon.

\section{REFERENCES}

Bender, M., Broecker, W., Gornitz, V., Middel, U., Kay, R., Sun, S.S. and Biscaye, P., 1971 Geochemistry of three cores from the East Pacific Rise. Earth Planet. Sci. Lett., 12: 425 433.

Bonatti, E. and Joensuu, O., 1966. Deep-sea iron deposit from the South Pacific. Science, 154: 643-645.

Chester, R. and Aston, R., 1976. The geochemistry of deep-sea sediments. In: J.P. Riley and R. Chester (Editors), Chemical Oceanography, Vol. 6, 2nd Edn., Academic Press, London, pp. 281-390.

Corliss, J.B., Dymond, J., Gordon, L.I., Edmond, J.M., von Herzen, R.P., Ballard, R.D., Green, K., Williams, D., Bainbridge, A.E., Crane, K. and van Andel, Tj.H., 1979. Submarine thermal springs on the Galapagos Rift. Science, 203: 1073-1083.

Dams, R. and Robbins, V.A., 1970. Nondestructive Activation Analysis of Environmental Samples. Univ. Michigan Great Lakes Res. Div., Tech. Rep. 48, 92 pp.

de Baar, H.J.W., Bacon, M.P. and Brewer, P.G., 1985. Rare earth elements in the Pacific and Atlantic Oceans. Geochim. Cosmochim. Acta, 49: 1943-1959. 
DeMaster, D.J., 1981. The supply and accumulation of silica in the marine environment. Geochim. Cosmochim. Acta, 45: 1715-1732.

Dymond, J., 1981. The geochemistry of Nazca Plate surface sediments: an evaluation of hydrothermal, biogenic, detrital, and hydrogenous sources. In: L.D. Kulm, J. Dymond, E.J. Dasch and D.M. Hussong (Editors), Nazca Plate: Crustal Formation and Andean Convergence. Geol. Soc. Am., Mem. 154, pp. 133-174.

Dymond, J., Corliss, J.B., Heath, G.R., Field, C.W., Dasch, E.J. and Veeh, H.H., 1973. Origin of metalliferous sediments from the Pacific Ocean. Geol. Soc. Am. Bull., 84: 3355-3372.

Edmond, J.M., Measures, C., McDuff, R., Chan, L.H., Collier, R., Grant, B., Gordon, L.I. and Corliss, J.B., 1979. Ridge-crest hydrothermal activity and the balances of the major and minor elements in the ocean: The Galapagos data. Earth Planet. Sci. Lett., 46: 1-18.

Elderfield, H. and Sholkovitz, E.R., 1987. Rare earth elements in the pore waters of reducing nearshore sediments. Earth Planet. Sci. Lett., 82: 280-288.

Elderfield, H., Hawkesworth, C.J., Greaves, M.J. and Calvert, S.E., 1981a. Rare earth element geochemistry of oceanic ferromanganese nodules and associated sediments. Geochim. Cosmochim. Acta, 45: 513-528.

Elderfield, H., Hawkesworth, C.J., Greaves, M.J. and Calvert, S.E., 1981b. Rare earth element zoneation in Pacific ferromanganese nodules. Geochim. Cosmochim. Acta, 45: 1231- 1234.

Erzinger, J., 1986. Interlaboratory comparison of Leg 92 standard basalt sample analyses. In: M. Leinen and D.K. Rea (Editors), Initial Reports of the Deep Sea Drilling Project, Vol. XCII. U.S. Gov. Print. Office, Washington, pp. 433-434.

Fleet, A.J., 1984. Aqueous and sedimentary geochemistry of the rare earth elements. In: P. Henderson (Editor), Rare Earth Element Geochemistry. Elsevier, Amsterdam, pp. 343-373.

Fox, D.J. and Guire, K.E., 1976. Documentation for MIDAS, 3rd Edn. Statistical Research Laboratory, University of Michigan, Ann Arbor, 203 pp.

Gordon, C.E., Randle, K., Goles, G.D., Corliss, J.B., Beesen, M.H. and Oxley, S.S., 1968. Instrumental analysis of standard rocks with high resolution X-ray detectors. Geochim. Cosmochim. Acta, 32: 364-396.

Graybeal, A.L. and Heath, G.R., 1984. Remobilization of transition metals in surficial pelagic sediments from the eastern Pacific. Geochim. Cosmochim. Acta, 48: 965-975.

Grimaud, D., Michard, A. and Michard, G., 1984. Composition chimique et composition isotopique du strontium dans les eaux hydrothermales sousmarines de la dorsale EST-Pacifique a $13^{2}$ N. C.R. Acad. Sci. Paris, 299: 865-870.

Høgdahl, O,T., Melsom, S. and Bowen, V.T., 1968. Neutron activation of lanthanide elements in seawater. Adv. Chem. Ser., 73: 308-325.

Hoyle, J., Elderfield, H., Gledhill, A. and Greaves, M., 1984. The behavior of the rare earth elements during mixing of river and sea waters. Geochim. Cosmochim. Acta, 48: 143-149.

Keasler, K.M. and Loveland, W.D., 1982. Rare earth elemental concentrations in some Pacific Northwest rivers. Earth Planet. Sci. Lett., 61: 68-72.

Klinkhammer, G., Elderfield, H. and Hudson, A., 1983. Rare earth elements in seawater near hydrothermal vents. Nature, 305: 185-188.

Kolesov, G.M., Anikiyev, X.X. and Sarenko, V.S., 1975. On the geochemistry of rare earth elements in the waters of the Black Sea (translation). Geochem. Int., 12: 82-88.

Leinen, M. and Pisias, N., 1984. An objective technique for determining end-member compositions and for partitioning sediments according to their sources. Geochim. Cosmochim. Acta. 48: 47-62.

Lupton, J.E. and Craig, H., 1981. A major helium-3 source at $15^{\circ} \mathrm{S}$ on the East Pacific Rise. Science, 214: 13-18.

Lyle, M.W., Owen, R.M. and Leinen, M., 1986. History of hydrothermal sedimentation at the East Pacific Rise, $19^{\circ}$ S. In: M. Leinen and D.K. Rea (Editors), Initial Reports of the Deep Sea Drilling Project, Vol. XCII. U.S. Gov. Print. Office, Washington, pp. 585-596. 
Lyle, M., Leinen, M., Owen, R.M. and Rea, D.K., 1987. Late Tertiary history of hydrothermal disposition at the East Pacific Rise, $19^{\circ} \mathrm{S}$ : correlation to volcano-tectonic events. Geophys. Res. Lett., 14: 595-598.

Martin, J.M., Høgdahl, O. and Philippot, J.C., 1976. Rare earth element supply to the ocean. J. Geophys. Res., 81: 3119-3124.

McDuff, R.E., 1987. Chemistry of seafloor hydrothermal systems. Rev. Geophys., 25: 1427-1429.

Michard, A. and Albarede, F., 1986. The REE content of some hydrothermal fluids. Chem. Geol., 55: $51-60$.

Olivarez, A.M. and Owen, R.M., 1987. Scavenging and mass accumulation of rare earth elements in Pacific hydrothermal precipitates. EOS: Trans. Am. Geophys. Union, 68: 1326.

Owen, R.M. and Mackin, J.E., 1980. Authigenic associations between selected rare earth elements and trace metals in lacustrine sediments. Environ. Geol., 3: 131-137.

Piper, D.Z., 1974. Rare earths in the sedimentary cycle: a summary. Chem. Geol., 12: 285-304.

Piper, D.Z. and Graef, P., 1974. Gold and rare earth elements in sediments from the East Pacific Rise. Mar. Geol., 17: 287-297.

Piper, D.Z., Veeh, H.H., Bertrand, W.G. and Chase, R.L., 1975. An iron-rich deposit from the northeast Pacific. Earth Planet. Sci. Lett., 26: 114-120.

Rona, P.A., Bostrom, K., Laubier, L. and Smith, K.L., Jr. (Editors), 1983. Hydrothermal Processes at Seafloor Spreading Centers. Plenum Press, New York, 796 pp.

Ruhlin, D.E. and Owen, R.M., 1986a. The rare earth element geochemistry of hydrothermal sediments from the East Pacific Rise: Examination of a seawater scavenging mechanism. Geo. chim. Cosmochim. Acta, 50: 393-400.

Ruhlin, D.E. and Owen, R.M., 1986b. Factors influencing the rare earth element composition of hydrothermal precipitates, East Pacific Rise. In: M. Leinen and D.K. Rea (Editors), Initial Reports of the Deep Sea Drilling Project, Vol. XCII. U.S. Gov. Print. Office, Washington, pp. 383-389.

Von Damm, K.L., Edmond, J.M., Grant, B., Measures, C.I., Walden, B. and Weiss, R.F., 1985. Chemistry of hydrothermal solutions at $21^{\circ} \mathrm{N}$, East Pacific Rise. Geochim. Cosmochim. Acta. 49: 2221-2237.

Varshal, G.N., Senyavin, M.M. and Yartseva, R.D., 1975. Forms of calcium and REE in river waters. In: A.E. Tugarinov (Editor), Recent Contributions to Geochemistry and Analytical Chemistry, Wiley, New York, pp. 597-603.

Vine, F.J., 1966. Spreading of the ocean floor: new evidence. Science, 154: 1405-1415. 